\title{
Relationship between Financial Compensation and Organizational Commitment among Malaysian Bank Workers
}

\author{
Low Bee Kee ${ }^{1}$, Rusli bin Ahmad ${ }^{1} \&$ Siti Mariam Abdullah ${ }^{1}$ \\ ${ }^{1}$ Faculty of Cognitive Sciences and Human Development, University Malaysia Sarawak, Malaysia \\ Correspondence: Rusli bin Ahmad, Faculty of Cognitive Sciences and Human Development, University Malaysia \\ Sarawak, Malaysia. E-mail: rusli@unimas.my
}

Received: January 29, 2016

Accepted: February 4, $2016 \quad$ Online Published: February 29, 2016

doi:10.20849/abr.v1i1.29

URL: http://dx.doi.org/10.20849/abr.v1i1.29

\begin{abstract}
This research examines the relationship between financial compensation and organizational commitment among workers in the banking industry, Malaysia. This research is significant in addressing the preceding gap on the types of financial compensation such as salaries, bonuses and merit pay with a stronger relationship with organizational commitment. Although these variables have been widely studied, few studies have explored their relationship to organizational commitment. Quantitative methodology is utilized to explore the relationship between financial compensation and organizational commitment. In data collection, a questionnaire was administered among 150 workers working in several selected banks in Bera; a town situated in the state of Pahang, Malaysia. Simple random sampling was used to select the respondents in the survey. The research findings showed that there is a significant relationship between financial compensation such as salaries, bonuses and merit pay and organizational commitment. Besides that, merit-based pay is identified as the dominant factor in influencing the organizational commitment among the bank workers under study. The research findings contribute to a better understanding for all related parties on the application of theories and model in relation with financial compensation aspects and organizational commitment.
\end{abstract}

Keywords: bonuses, financial compensation, organizational commitment, merit pay, salaries

\section{Introduction}

This research is to determine the relationship between financial compensation and organizational commitment among workers in the organization. Financial compensation can be seen as a strategy in human resource management to attract, retain and motivate the workers in the changing environment (Issues in compensation management, 2014). Retention of workers lead to organizational commitment as well as minimizing the turnover rate in the organization (Studies prove, 2014). In turn, organizational commitment is the workers desire to stay with the particular organization and willingness to be involved towards achieving the organization goals (Bozlagan, Dogan, \& Daoudov, 2010). Committed workers who are satisfied with the job have low intention to leave the organization; thereby reducing workers' absenteeism and turnover rate in the organization (Ismail, 2012). Past research has shown that there is a positive relationship between compensation and organizational commitment. Thus, organizations provide such financial compensation as the strategy in human resource management to improve organizational commitment among the workers (Ahmad, Toh, \& Bujang, 2013).

\section{Literature}

Financial compensation is usually addressed in the human resource management strategic plan to support organization goals leading to organizational growth. Many organizations see financial compensation as a mediator to attract talented workers, motivate and increase the retention rate of their workers to stay with the organization (Ahmad et al., 2013). A proper compensation system may boost the workers' desire to stay with the organization, with job satisfaction and expectations, indirectly becoming higher (Munap, Mohd, \& Abdul, 2013). In this context Riggio (2013) stated clearly that workers are motivated by money and material gains. Mercer report (2003) also has indicated that with fair and equitable compensation, workers are more likely to stay with the organization.

From research findings, it is clear that the element of financial benefits motivate workers. Malik, Danish, and Munir (2012) in their study in Pakistan found that the higher the amount of pay, the higher the job satisfaction. In relation, a study by Scott and McMullen (2010) showed $42 \%$ of the respondents agreed that the total reward 
strategies had a positive effect on employee engagement and reduced particular issues of the organization such as turnover, organizational justice and absenteeism. Other studies on organizational commitment such as Bashir and Long (2015) has shown that training-related variables also have a significant and positive relationship with organisational commitment in Malaysia. Malaysian workers are seeking other intrinsic factors for example career development, recognition and work life balance as job attractions which tend to contribute more towards retention of talented workers rather than a higher pay. Studied by Anvari, Mohammad Amin, Ungku Ahmad, Seliman and Garmsari, (2011) found that expectation or belief of the workers, contribute to hard work and in return good for the issues of fairness in organization.

\subsection{Financial Compensation}

Compensation is a kind of financial benefits to attract and motivate workers in the organization. According to Anavari et al. (2011), strategic compensation is an important component associated with employee behavior and attitude towards improving organizational achievement by increasing organizational commitment and motivation among the workers. Rizal, Idrus, Djumahir and Mintarti (2014), in their study also found that financial and non-financial compensation may affect motivation and performance.

\subsection{Salary}

Related studies show that salary is the one of the strategies in motivating the workers, in order to enhance their performance, commitment and satisfaction. It may influence the workers' behavior as well as attract, and increase the intention to stay and lead to the higher performance in the organization (Tella et al., 2007). Pay satisfaction had a significant positive relationship with the organizational commitment (Ramay, 2011). In a similar study by Munap et al. (2013), salary was one of the factors that can influence the probability of decision making for the workers to join, leave or stay in the organization. However, another study by Al-Zoubi (2012) indicated that salaries have a low influence toward workers' job satisfaction whereby the job position of the workers leads to better job satisfaction rather than higher salaries.

\subsection{Bonus}

According to the study by Park and Sturman (2009), it is stated that the popularity of the bonus pay system has increased and is widely used in organizations. Most organizations are offering bonus pay as a one-time cash reward to enhance and motivate the workers' working performance. It is given based on the workers' productivity and is an additional annual payout. Lopez (2006) claimed that bonus pay might increase retention to stay or exit in a study on the retention commitment of soldiers in a hostile environment. However, the retention bonus could not be a long term measure and scored a moderate percentage in continuing to retain the army, although it played an important role in decision making; to leave or stay. Additionally, Tzu and Chung (2007) claimed that the bonuses given to the workers are used to improve the operational efficiency thereby motivating them to work harder in order to receive a high amount of future bonuses depending on the productivity of the organization. In addition, the bonus payment system may reduce the turnover issue among workers who are likely to quit the organization. It also tends to attract talented workers and generally motivates workers to perform better.

\subsection{Merit - Based Pay}

According to Gorton (1994), merit- based pay play a vital role to bring job satisfaction, organizational commitment and job performance whereby most organization are using the merit based pay system as a strategic reward plan that can enhance the workers performance and influence the workers' working behavior toward higher fulfillment with the organization. Besides that, the merit-based pay system exerts a strong power to retain workers and influence their decision to stay or leave the organization. Thus, many companies have attempted to implement the merit- based pay compensation program for the workers. The workers desire the opportunity to receive additional payment based on their performance, a means to gain extra money over their basic payment (Jensen, 2014). In contrary, Chooi and Whitford (2013) state that the merit- based pay has a negative influence on job satisfaction. The results are not comparable with most previous studies. The merit- based pay plan may not have the desired strong relationship with job performance ratings in the organization and shows that there are not large differences in payment between the best performer and the worst performer (Park \& Sturman, 2009).

\subsection{Organizational Commitment}

In Allen and Meyer's study (as cited in Warsi, Fatima, \& Sahibzada, 2009), the three-component model of organizational commitment consists of affective, continuance and normative commitment. Affective organizational commitment refers to the strong feelings attached to the organization, feeling affection for the job and likely to be involved in organizational activities to achieve its goals and values. Continuance organizational commitment refers to the strong feeling for fear of losing their benefits and economic ties to their organization if 
they leave the organization. Normative organizational commitment is the sense of obligation to stay with the organization. An employee with strong normative organizational commitment may think that is normal and perhaps there are rewards provided in advance (Ismail, 2012).

Based on the study of Leow and Khong (2009) that was conducted in Malaysia, organizational commitment is strongly related to the employee's intention to leave or stay with the organization and it plays a vital role to strengthen the organization growth. In addition, various studies have indicated a strong link between job satisfaction and organizational commitment. If workers are satisfied with their job, they are more committed in their jobs and organization (Ismail, 2012; Karim \& Rehman, 2012; Warsi et. al., 2009).

Although the variables of financial compensation and organizational commitment have been widely researched, this study aims to determine the type of financial compensation with a stronger relationship towards organizational commitment among the workers in selected banks in Malaysia.

\section{Research Objectives}

Generally this research attempts to determine the relationship between financial compensation towards organizational commitment among selected bank workers. The specific objectives identified are as follows;

1. To determine the relationship between salaries and organizational commitment among the workers in the organization.

2. To determine the relationship between bonuses and organizational commitment among the workers in the organization.

3. To determine the relationship between the merit-based pay and organizational commitment among the workers in the organization.

4. To identify the dominant factor among three types of financial compensation in influencing organizational commitment among the workers in the organization.

\subsection{Research Hypotheses}

Based on the research objectives, the following hypotheses were developed and tested:

Ha1: There is a significant relationship between salaries and organizational commitment among the workers in the organization.

$\mathrm{Ha} 2$ : There is a significant relationship between bonuses and organizational commitment among the workers in the organization.

Ha3: There is a significant relationship between merit-based pay and organizational commitment among the workers in the organization.

Ha4: There is a dominant factor among the three types of financial compensation in influencing organizational commitment among the workers in the organization.

The above hypotheses were supported by a related previous study. A study by Parvin and Kabir (2011) indicated that salaries were one of the motivators for organizational commitment in the organization which enhances the attraction and retention of the workers. Tzu and Chung (2007) found that bonuses are likely to induce the workers to become more committed to the organization helping to accomplish organizational goals and improve organizational operations. The above hypothesis on merit-based pay and organizational commitment is supported by the study of Ibrahim and Boerhaneoddin (2010). They found that workers who were compensated in meritbased pay are more likely to experience higher employment stability.

\section{Significance of Study}

This study hopes to contribute useful information for several parties as well as for the researcher. The research will be significant in addressing the preceding gap of the types of financial compensation such as salaries, bonuses and merit pay with a stronger relationship with organizational commitment. The final findings provide reliable statistical data results useful for other researchers to further investigate the topic. Determining the relationship between financial compensation and organizational commitment will guide organizations to identify appropriate ways to motivate their workers and improve job satisfaction leading to organizational commitment. Besides that, this study provides clear viewpoints on the types of financial compensation which will possibly lead to more commitment among workers and help to fulfill their needs toward the financial compensation.

This research will also provide further insights on the compensation policy in an organization as part of the human resource strategic plan to attract and retain talented workers. Therefore, this research study may bring some 
benefits to the organization and the researcher in order to better understand the factors that will increase organizational commitment among workers, and come out with a well-designed compensation policy especially in the Malaysian setting in the hope that well-compensated workers will reduce the turnover rate in organizations.

\section{Research Design}

The quantitative research methodology is used to validate the relationship between the variables and verify the research hypotheses rather than depth understanding about complex situation (Ahmad \& Usop, 2011). Therefore, in order to determine the relationship between financial compensation and organizational commitment, the most appropriate research methodology used for this study is quantitative methodology, because the quantitative research is a suitable framework to explore the relationship between the variables. According to Ahmad and Usop (2011), among the advantages of using quantitative methodology as a framework to conduct the research methodology are: less expensive, confidentiality is assured, data analysis is simple and less time consuming rather than direct interaction with the respondents. On the other hand, some weaknesses of quantitative methodology such as a greater chance of bias, the results of the research are hard to interpret and higher interpretation skills are needed. Quantitative research also does not offer indepth explanation about the results of study.

\subsection{Location, Population and Sample}

This study was conducted on a total targeted population of 150 people workers who work in several selected banks in Bera, Pahang, Malaysia. Job classification of the sample encompassed customer service department, administrative department, management group (e.g. manager, supervisor, administrators, etc.) in various positions and salary levels. This research is based on simple random sampling technique. The respondents assigned were allocated numbers and listed consecutively in tabulated form from which the numbers of the respondents were selected randomly for the sample. This simple random method of sampling is used in this research because it is an unbiased random selection in which each respondent has equal chance of being selected in the survey. The result of the sampling is more generalized because the sample reflects the similar characteristic to representative the whole population. In order to generalize the sample size of the total targeted population, Slovin's formula is used to determine the minimum sample size of the respondents that is representative of the population for this research. Besides that, by using Slovin's formula, the margin error is allowed for the probability of an error during the process of selecting respondents (Padua \& Santos, 2012).

\subsection{Data Collection Technique}

The questionnaire survey was chosen as the instrument of data collection in the research. A questionnaire survey can involve large number of samples with no geographical restrictions. Data was collected by using closed-ended items with a fixed set of answers from which the respondents chose from. The instrument that was used to measure the variables of was adapted from measures that have been developed by several previous researchers. The questionnaire is organized into four sections. Section A is the demographic background of the respondents such as gender, age, race, ethic and working experience. This is followed by Section B; the variable of salary and Section $\mathrm{C}$; the variable of bonus. Section D is about merit-based pay. The items for each variable are mostly adapted from the sources of Employee opinion survey demo, (2014). Lastly, Section E is about the variable of organizational commitment adapted from Mowday et al. (1979). The questionnaire has a five point Likert scale in which respondents rank accordingly with $1=$ strongly disagree, $2=$ disagree, $3=$ neutral, $4=$ agree and lastly $5=$ strongly agree, with regards to each item. The data collection technique is through face to face interaction. 200 sets of questionnaire were distributed to the respondents in person along with a brief explanation of its purpose. Preceding data collection, permission was granted for data collection from the organisation. After a week, the completed questionnaires were collected by the researcher.

\subsection{Validity and Reliability}

The validity and reliability of the questionnaire is of vital concern to the researcher. Hence, a pilot test is conducted before the actual study. According to Johnson and Christensen (2013), a minimum of 5 - 10 people should be involved in the questionnaire pilot testing in order to ensure the quality of the questions to meet the objectives of the study. Thus, 30 sets of questionnaire were distributed to pilot test for validity. The draft of the questionnaire was discussed with the research supervisor who gave guidance on the format, structuring, grammar and wording. The purpose of the pilot testing is mainly to ensure the items in the questionnaire are logically connected to the objectives of the research and to detect the errors in the questionnaire (Ahmad \& Usop, 2011). The language was also checked as the questionnaire was bilingual; in English and Bahasa Malaysia to enhance comprehension among the respondents. 
The reliability of the questionnaire is very crucial too, because it helps to determine if the same results will be obtained when re-administered to the same respondents and it will not be affected by the respondents' physical setting. The statistical tool used to measure the reliability of the questionnaire is Cronbach's Alpha. The Cronbach's Alpha value range in 0-1.0 represents the scale of reliability; the higher the Cronbach's Alpha value, the more reliable is the item in the questionnaire. The Cronbach's Alpha value of 0.7 was adopted as any value above is acceptable; the lower value is considering not a reliable questionnaire. There would be a need to correct and re-examined the items in the questionnaire if the reliability level is below acceptable level (Santos, 1999).

\subsection{Data Analysis and Ethics}

Once the data has been collected, the numerical data was recorded and analysed by using the Statistical Package for the Social Sciences (SPSS) Version 19 software programme. The outcome evaluation of statistical data is using inferential statistics. The inferential statistic test included the t-test which compared the means from two different samples and Pearson's correlation coefficient which related the independent and dependent variables to test each research hypothesis in line with the stated research objectives. Inferential statistics was used to make the data more generalized from the population.

Some ethical considerations were addressed before conducting data collection. Respondents in the study participated on a voluntary basis and permission to conduct the study was obtained prior to administration of the questionnaires. The aims and objectives of this study were fully informed before the data collection process. In addition, the privacy of the respondents involved are ensured with the data provided kept private and confidential. The researcher took care not to harm any respondent or any parties involved during the research process. Lastly, the research questionnaire was used solely to collect the information for academic purpose. The questionnaire did not contain any discriminating, biased wording and no personal and sensitive questions were asked of the respondents.

\section{Research Findings and Discussion}

The research findings and discussion in this study are reported based on the stated objectives in a bid to systematically present the findings to readers.

\subsection{The Relationship between Salary System and Organizational Commitment}

The research objective above was tested using Pearson Correlation technique and the results on the identified research hypothesis of the relationship between the salary system and organizational commitment are shown below:

Ha1: There is a significant relationship between salary system and organizational commitment among the workers in the organization

Table 1. Pearson correlation between salary system and organizational commitment

\begin{tabular}{ccc}
\hline Variables & Pearson Correlation & Significance \\
\hline Salary & 1 & $.588^{* *}$ \\
Organizational Commitment & $.588^{* *}$ & 1
\end{tabular}

**. Correlation is significant at the 0.01 level (2-tailed).

Based on Table 1 above, the Pearson's $r$ value for the correlation between the salary system and organizational commitment where $(\mathrm{r}=0.588)$. When Pearson's $\mathrm{r}$ is close to 1 , it means that there is a strong relationship between the two variables. As shown in the table, the Pearson's $r$ is close to 0.5. It indicates there is a moderate positive relationship between the salary system and organizational commitment. The two variables are correlated to each other; when one variable increases in value, the second variable will also increase in value. Similarly, as one variable decreases in value, the second variable also will decrease in value. Therefore, it called as positive correlation. From the table, the Pearson's $r$ value of 0.588 indicates positive value. Since our Pearson's $r$ value is positive, we can conclude that when the salary increases, the organizational commitment also increases. In the Correlations analysis result, the $\mathrm{r}$ value will show us if there is a statistically significant correlation between salary system and organizational commitment.

As shown in Table 1 above, the Sig. (2-tailed) value is 0.00 which is less than 0.01 . Therefore, there is a statistically significant correlation between our two variables. Thus, we conclude that Hal is accepted. Likewise, 
the increases or decreases in salary system is significantly related to increases or decreases in organizational commitment. This finding is supported by Rizqi and Ridwan (2015), who stated that pay satisfaction may affect the organizational commitment and pay satisfaction, was positively correlated with organizational commitment. This result also supports Herzberg's Two Factor theory which states that workers are truly motivated or satisfaction when the motivator factors present (Riggio, 2013). Besides that, the study of Munap et al. (2013) stated that, salary as the one of the factors that can influence the probability of decision making for the workers to join, leave or stay in the organization. From the view of practical, salary is a management tool for work performance and good pay induces commitment (EkonomitMer, 2015). In additional, salary is as one of the types of financial incentives is less attractive in motivating workers as there is a medium positive relationship between salary and organizational commitment (Beyond the bonus, 2013).

\subsection{The Relationship between Bonus System and Organizational Commitment}

The research objective above was tested using Pearson Correlation technique and the results on the identified research hypothesis of the relationship between bonus system and organizational commitment are shown below:

$\mathrm{Ha} 2$ : There is a significant relationship between bonus system and organizational commitment among the workers in the organization.

Table 2. Pearson correlation between bonus and organizational commitment

\begin{tabular}{ccc}
\hline Variables & Pearson Correlation & Significance \\
\hline Bonus & 1 & $.711^{* *}$ \\
Organizational Commitment & $.711^{* *}$ & 1 \\
\hline
\end{tabular}

**. Correlation is significant at the 0.01 level (2-tailed).

Based on Table 2, the Pearson's $r$ value for the correlation between bonus system and organizational commitment where $(r=0.711)$. When Pearson's $r$ is close to 1 , it means that there is a strong relationship between two variables. As the table shown, Pearson's $r$ value is close to 1.0. That means there is a strong positive relationship between bonus systems and organizational commitment. Two variables are correlated with each other. When one variable increases in value, the second variable will also increase in value. Similarly, as one variable decreases in value, the second variable also will decreases in value. Therefore, it called as positive correlation. From the table, Pearson's $r$ value of 0.711 which is positive value. Since our Pearson's $r$ value is positive, we can conclude that when the bonus increases, the organizational commitment also increase. In the Correlations analysis result, the $r$ value show us if there is a statistically significant correlation between salary system and organizational commitment.

As shown in table 2, the Sig. (2-tailed) value is 0.00 which is less than 0.01 . Therefore, it indicated a statistically significant correlation between our two variables. Thus, we can conclude that Ha2 is accepted. Likewise, the increases or decreases in bonus system is significantly relate to increases or decreases in organizational commitment. The finding is supported by Lopez (2006); Tzu and Chung (2007), which examined bonus pay has a significant positive relationship with organizational commitment. The bonus pay might increase the intention and motivate the workers to stay with the organization. Evidence from the study of Institute of Leadership and Management (ILM) shows $13 \%$ of the workers said they are motivated by a bonus. Getting a bonus for performing well is one of the motivational factors (Beyond the bonus, 2013). The findings showing there is a significant positive correlation between bonus and organizational commitment is reinforced by Adam's Equity theory in which the degree of perceived fairness on compensation may influence their motivation and intention to stay with the organization (Hassan, 2002).

\subsection{The Relationship between Merits - Based Pay and Organizational Commitment}

The research objective above was tested using Pearson Correlation technique and results on the identified research hypothesis of the relationship between the merit-based pay and organizational commitment are shown below:

Ha3: There is a significant relationship between merits-based pay and organizational commitment among the workers in the organization. 
Table 3. Pearson correlation between merit-based pay and organizational commitment

\begin{tabular}{ccc}
\hline Variables & Pearson Correlation & Significance \\
\hline Merit-based Pay & 1 & $.753^{* *}$ \\
Organizational Commitment & $.753^{* *}$ & 1 \\
\hline
\end{tabular}

**. Correlation is significant at the 0.01 level (2-tailed).

Based on Table 3, the Pearson's $r$ value for the correlation between the merits based pay system and organizational commitment where $(\mathrm{r}=0.753)$. When Pearson's $r$ is close to 1 , it means that there is a strong relationship between two variables. As the table shown, Pearson's $r$ value is close to 1.0. That means there is a strong positive relationship between merits based pay systems and organizational commitment. Two variables are correlated with each other. When one variable increases in value, the second variable will also increase in value. Similarly, as one variable decreases in value, the second variable also will decreases in value. Therefore, it called as positive correlation. From the table, Pearson's $r$ value of 0.753 is of positive value. Since our Pearson's $r$ value is positive, we can conclude that both variables are interrelated. When the merits based pay increases, the organizational commitment also increase. In the Correlations analysis result, the $\mathrm{r}$ value show us if there is a statistically significant correlation between salary system and organizational commitment.

Table 3 shows that the Sig. (2-tailed) value is 0.00 which is less than 0.05 . Therefore, it indicated a statistically significant correlation between our two variables. Thus, we conclude that $\mathrm{Ha} 3$ is accepted. Likewise, the increases or decreases in merits based pay system is significantly relate to increases or decreases in organizational commitment. Gorton (1994) stated merit based pay system as a strong power to retain the workers and influence the workers' decision to stay or leave the organization. Adversely, the research finding result is not comparable with the study of Rizal et al. (2014) which indicates that the relationship between merit-based pay and organizational commitment is small.

\subsection{Dominant Factor among Three Types of Financial Compensation in Influencing Organizational Commitment}

The research objective above was tested using Multiple Regression technique and results on results finding of the dominant factor among three types of financial compensation in influencing organizational commitment are shown below:

$\mathrm{Ha} 4$ : There is a dominant factor among the three types of financial compensation in influencing the organizational commitment among the workers in the organization.

Table 4. The multiple regression analysis result

\begin{tabular}{|c|c|c|c|c|c|}
\hline \multirow[t]{2}{*}{ Model } & \multicolumn{2}{|c|}{$\begin{array}{l}\text { Unstandardized } \\
\text { Coefficients }\end{array}$} & $\begin{array}{l}\text { Standardized } \\
\text { Coefficients }\end{array}$ & \multirow[t]{2}{*}{$\mathrm{t}$} & \multirow[t]{2}{*}{ Sig. } \\
\hline & B & Std. I & Beta & & \\
\hline Salary & .155 & .059 & .192 & 2.633 & .010 \\
\hline Bonus & .225 & .075 & .279 & 3.021 & .003 \\
\hline Merit-based pay & .402 & .088 & .432 & 4.582 & .000 \\
\hline
\end{tabular}

a. Dependent variable: organizational commitment

Regression analysis is used to determine the dominant factor among the three types of financial compensation in influencing the organizational commitment among the workers in the organization by identifying the biggest Beta value. As shown in Table 4 above, the significant value of bonus and merit-based pay is less than 0.05 which is a significant relationship in influencing organizational commitment. Based on the table above, the Beta value for merit-based pay are the biggest beta value compare to salary and bonus where (Beta=0.432). Thus, we can conclude that merit-based pay is the dominant factor in influencing the organizational commitment among the workers in the organization. The evidence from the Federal Employee viewpoint survey shows that the merit-based pay seen as effective motivator in influencing the effectiveness of an organization like organizational commitment, absenteeism and turnover rate (Chooi \& Whitford, 2013). 


\section{Implications of the Study}

These research findings have several implications which can contribute to three parties which are: implication to the organization, human resources practitioners and future researchers. This study contributes useful information and it creates a better understanding for organization towards the financial compensation which will lead to organizational commitment. From this study, the organization can identify the dominant factor that can lead to the strongest relationship between the financial compensation and organization commitment. Therefore, the organization can improve their policy on financial compensation and create a more effective and efficient organization by increasing workers' organizational commitment.

This study creates awareness among human resource practitioner on the importance of the relationship between financial compensation and organizational commitment. Human resource practitioners can develop a new compensation system in order to increase organizational commitment among the workers and also helps to minimize turnover and increase workers' motivation, albeit indirectly. A strategic compensation system is certainly vital to assist in increased motivation and organizational commitment of the workers.

Furthermore, the research finding results are highly exploratory for further studies. The research findings contribute to a better understanding for future researcher about the application of theories and model which had been discussed in this study. Future researchers can investigate the organizational commitment model and motivation theory in their future studies.

\section{Limitations}

There are some limitations in this study. First, the measurement of the variables of financial compensation and organizational commitment is only based on a closed-ended questionnaire and the respondents only answer the questionnaire from a fixed set of answers. The respondents might not be honest in answering the questionnaire. Time constraint is another limitation in this study. The questionnaire was distributed to the respondents within a specific period of time; the respondents might be not enough time to answer the questions. Besides that, another limitation study is language barrier. The questionnaire was bilingual, in English and Bahasa Malaysia. However, the respondents were encouraged to answer the questionnaire in English which might have given rise to uncertainty and misunderstanding between two languages. As such, , the respondents might not have answered the questionnaire with a clear understanding and caused biased responses due to the poor understanding of the items in the questionnaire.

\section{Recommendations}

Based on this study, the following additional studies are recommended to organization; human resource practitioner and future researcher. Organization should develop and implement an adequate financial compensation system and policy in the organization in order to motivate workers' retention to stay with the organization. An effective compensation strategy serves to motivate current workers and attract new ones. The organization can redefine a new approach to compensation management. It is important to integrate a structured compensation management into the organization. It make sure the human resource practitioner are well understanding on the beneficial of the financial compensation and in can be a foundation for creating a strong culture of organizational commitment among the workers. As the dominant factor of financial compensation in influencing organizational commitment is merit-based pay, it is the most effective way to encourage the workers to stay with the organization. Therefore, the organization should emphasize the transparency of performance evaluation systems for it to be perceived as fair in order for it to have more motivating power.

Human resource practitioners should make sure the compensation system and policy are stated under the organization's accepted laws and legislation for example, the overtime payment and minimum wages policy. Besides that, human resource practitioners are responsible to ensure should all of the workers in the organization are completely understanding on the compensation system and policy in the organization.

Concerning future studies, the scope of study can be extended to include other types of financial compensation system with moderating variable of gender which was not discussed in this study. It will describe the differences in perspective of gender. Other than that, future researchers also can focus more deeply on possible types of financial compensation system in mediating the organizational commitment such as direct and indirect financial compensation. In addition, future researchers are encouraged to focus more on qualitative research instead of quantitative research. Qualitative research can discuss a more comprehensive perspective of workers on the current financial compensation system and policies rather than limited to responding to a closed-ended questionnaire survey form. 
Future researchers also can conduct this study in other industries in a bigger population such as hotel industry, oil and gas industry and so on. By conducting this study in future, it may bring a more reliable and valid research findings and it also provide a different preferences in others industry. Therefore, the organization can have a better knowledge on the compensation system and implement the research findings to develop an adequate compensation system and policy. In addition, this study also suggests that future researchers should have better time management for each process of the research. Future researchers should have a time schedule in making lists or drawing up the plans and set up the priorities on which do first, take every process in a time to accomplish the research study in a short period of time.

\section{Conclusion}

In conclusion, the research finding showed that there is a significant relationship between independent variables and independent variables. Besides that, this research also identified merit-based pay as the dominant factor in influencing organizational commitment among the workers in the organization.

\section{References}

Admin, S. M., Ungku, A. U. N., Seliman, S. \& Garmsari, M. (2011). The relationship between strategic compensation practices and affective organizational commitment. Interdisciplinary journal of research in business, 1(2), 44-55.

Ahmad, R., \& Usop, H. (2011). Conducting research in social sciences, humanities, economics and management studies. Batu Kawa, Kuching: RS GROUP publishing house.

Ahmad, R., Toh, E. P. Y., \& Bujang, S. (2013). Relationship between types of benefit (leave, loan and retirement plan) and workers' retention. International journal of education and research, 1(8).

Anavari, R., Amin, S. M., Ungku, A. U. N., Seliman, S., \& Garmsari, M. (2011). The relationship between strategic compensation practices and affective organizational commitment. Interdisciplinary journal of research in business, 1(2), 44-55.

Al-Zoubi, M. T., (2012). The shape of the relationship between salary and job satisfaction: A field study. Far East journal of psychology and business, 7(3).

Bozlagan, R., Dogan, M., \& Daoudov, M. (2010). Organizational commitment and case study on the union of municipalities of Marmara. Regional and Sectorial Economic studies, 10(2), 30-33.

Caruth, D. L., \& Handlogten, G. D. (2001). Managing Compensation and understanding it too. Westport, United Stated: Greenwood Publishing group.

Chapman, A. (2014). Maslow's Hierarchy of Need. Retrieved from http://www.businessballs.com/maslow.htm

Chooi, S., \& Whitford, A. B. (2013). Merit-based pay and employee motivation in federal agencies. Retrieved from http://www.brookings.edu/ /media/research/files/papers/2013/11/26

Gorton, S. J. (1994). The influence or organizational justice on salesperson responses to merit pay decisions: an empirical investigation. Unpublished master's thesis, Iowa State University, Ames, Iowa.

Greenberg, J. (2011). Behavior in Organizations (10th ed.). London, United Kingdom: Pearson Education limited.

Hassan, A. (2002). Organizational justice as a determinant of organizational commitment and intention to leave. Asian academy of management journal, 7(2), 55-66.

Ibrahim, I. I., \& Boerhaneoddin, A. (2010). Is job satisfaction mediating the relationship between compensation structure and organizational commitment? A study in the Malaysian power utility. Retrieved from http://www.internationalconference.com.my/proceeding/icber2010_proceeding/PAPR_249

Ismail, N. (2012). Organizational commitment and job satisfaction among staff of higher learning education institution in Kelantan. Unpublished master's thesis, University Utara Malaysia, Kedah, Malaysia.

Jensen, A. (2014). Is performance based pay practical for your company? Retrieved from http://www.andrewjensen.net/is-performance-based-pay-practical-for your-company/

Johnson, R. B., \& Christensen, L. (2013). Educational research: Quantitative, qualitative, and mixed approaches (5th ed.).United Stated: SAGE publication.

Karim, F., \& Rehman, O., (2012). Impact of job satisfaction, perceived organizational ustice and employee empowerment on organizational ommitment in semi government organizations of Pakistan. Journal of business studies quarterly, 3(4), 92-104. 
Kaur, A. (2013). Maslow's Need Hierarchy Theory: Application and Criticisms. Global Journal of Management and Business Studies, 3(10), 1061-1064.

Kinicki, A., \& Kreitner, R. (2009). Organizational behavior: Key concepts, skills and best practices (4th ed.). New York, United States: McGraw - Hill.

Leow, K. H., \& Khong, K. W. (2009). Organizational commitment: The study of organizational justice and leader member exchange (LMX) among auditors in Malaysia. International journal of business and information, $4(2), 161-198$.

Lopez, L. (2006). Retention commitment of United States army initial term and mid-careersoldier in Iraq: A comparison of Meyer and Allen's three component model of organizational commitment. Journal of educational and social research, 3(3), 281-287.

Mercer Report. (2003). Mercer study raises red flags for employer pay and benefit plans (finding of the 2002 people at work survey). Human Resources Department Report, 8-15.

Ministry of business, innovation and employment. (2011). Wage and salary earner differences. Retrieved from http://www.dol.govt.nz/workplace/knowledgebase/item/1306

Mondy, J. R. (2008). Human Resource Management. New Jersey, London: Pearson Education Ltd.

Munap, R. Mohd, B. M. I., \& Abdul, R. B. (2013). Organizational reward System and workers' satisfaction at Telekom Malaysia Berhad. Journal of educational and social research, 3(3), 81-288.

Parvin, M. M., \& Kabir, N. (2011). Factors affecting employee job satisfaction of pharmaceutical sector. Australian Journal of Business and Management Research, 1(9), 113-123.

Mowday, R., Steers, R., \& Porter, L. (1979). The measurement of organizational commitment. Journal of Vocational Behavior, 14, 224-247.

Malik, M. E., Danish, R. Q., \& Munir, Y. (2012). The impact of pay and promotion on job satisfaction: Evidence form higher education institutes of Pakistan. American Journal of economics, 6(9).

Ramay, M. I. (2011). Antecedents of organizational commitment of banking sector workers in Pakistan. Serbian journal of management, 7(1), 89-102.

Rizal, M., Idrus, M. S., Djumahir, \& Mintarti, R. (2014). Effect of compensation on motivation, organizational commitment and employee performance (Studies at local revenue management in Kendari City). International Journal of business and management invention, 3(2), 64-79.

Padua, R. N., \& Santos, R. G. (2012). Fundamentals of educational research and data analysis. Quezon City: Goodwill Trading Co., Inc.

Paik, Y., Parboteeah, K. P., \& Shin, W. (2007). The relationship between perceived compensation, organizational commitment and job satisfaction: The case of Mexican workers in the Korean Maquiladoras. Int. J. of Human resource management, 18(10), 1768-1781.

Park, S., \& Sturman, M. C. (2009). The relative effect of merit pay, bonuses, ad long term incentives on future job performance. Retrieved from http://digitalcommons.ilr.cornell.edu/cri/7

Reid, A. R. (2008). Maslow's Theory of Motivation and Hierarchy of Human Needs: A Critical Analysis. Phd Qualifying Examination, University of California, Berkeley, US.

Riggio, R. E. (2013). Introduction to Industrial / Organizational Psychology (6th ed.). New Jersey, US: Pearson Education.

Rizqi, N. A., \& Ridwan. S. (2015). The effects of pay satisfaction and affective commitment on turnover intention. International Journal of Research Studies in Psychology, 4(2), 57-70.

Santos, J. R. A. (1999). Cronbach's Alpha: A Tool for Assessing the Reliability of Scales. The Journal of extension, $37(2)$.

Scott, D. (2010). The impact of rewards programs on employee engagement. Washington, DC. Studies prove employee retention matters, turnover is expensive. (2014). Retrieved from http://www.performph.com/studies-prove employee-retention-matters-turnover expensive/

Tella, A., Ayeni, C. O., \& Popoola, S. O. (2007). Work motivation, job satisfaction, and organizational commitment of library personnel in academic and research libraries in Oyo State, Nigeria. Retrieved from http://unllib.unl.edu/LPP/tella2.htm 
Tovey, A. (2013). Bonuses not the best way to motivate staff. Retrieved from http://www.telegraph.co.uk/finance/jobs/10392115/Bonuses-not-the-best-way tomotivate-staff.html

Tzu, S. H., \& Chung, H. S. (2007). The effects of bonus systems on firm performance in Taiwan's high- tech sector. Journal of comparative economic, 35(1), 235-249.

Warsi, S., Fatima, N., \& Sahibzada, S. (2009). Study on relationship between organizational commitment and its determinants among private sector workers of Pakistan. International review of business research papers, 5(3), 399-410.

\section{Copyrights}

Copyright for this article is retained by the author(s), with first publication rights granted to the journal.

This is an open-access article distributed under the terms and conditions of the Creative Commons Attribution license (http://creativecommons.org/licenses/by/3.0/). 